\title{
Co-composting of chicken manure with organic wastes: characterization of gases emissions and compost quality
}

\author{
Hyun Young Hwang ${ }^{1}$, Seong Heon Kim ${ }^{1}$, Myung Sook Kim', Seong Jin Park ${ }^{1}$ and Chang Hoon Lee ${ }^{2^{*}}$
}

\begin{abstract}
Co-composting of organic wastes is globally recognized to be effective method to dispose two or more wastes at once and minimize drawbacks of composting such as gases emissions and nutrient reduction. In this study, pilotscale experiments were conducted to characterize the co-composting process of chicken manure with cow manure (CC), swine manure (CS), plant residues plus mushroom media (CRM), on emissions of greenhouse gas, and ammonia, compost quality, maturity and their correlations. The results showed that cumulative flux of carbon dioxide $\left(\mathrm{CO}_{2}\right)$, methane $\left(\mathrm{CH}_{4}\right)$, nitrous oxide $\left(\mathrm{N}_{2} \mathrm{O}\right)$ and ammonia $\left(\mathrm{NH}_{3}\right)$ widely ranged like 38,211-50,830, 172-417, 98-142 and 118-927 $\mathrm{g} \mathrm{kg} \mathrm{dm}^{-1}$ day ${ }^{-1}$ respectively. It indicated the importance of selection for co-composting material. The $\mathrm{NH}_{3}$ emission was significantly increased by 4.3-7.9 times in CS and CRM, compared to OC and CC. Both of CS and CRM also showed longer thermophilic phase and later maturation were also observed in both treatments. Temperature was positively correlated with gases $(P<0.001)$ except $\mathrm{CH}_{4}$, and nitrogen content, $\mathrm{C} / \mathrm{N}$ ratio and nitrate nitrogen significantly affected emission of carbon and nitrogen $(P<0.001)$. In conclusion, for chicken manure composting, sole chicken manure or combination with cow manure could be suitable composting method to improve compost quality and minimize gases losses.
\end{abstract}

Keywords: $\mathrm{NH}_{3}$ emission, Greenhouse gas, Compost maturity, Livestock manure

\section{Introduction}

Livestock production has markedly increased with increasing global population growth and demand for livestock. To take an instance from the global demand for pig meat, chicken meat and chicken eggs, it was predicted to grow by $32 \%, 61 \%$, and $39 \%$, respectively, up to 2030 [1]. According to Korean Statistical Information Service estimates, poultry breeding, mostly chicken, has increased by $306 \%$ [2] and South Korea has 72 million head of chickens [3]. The intensive chicken production systems have produced huge amounts of manure containing considerable nutrients, heavy metals and pathogens [4-6].

\footnotetext{
*Correspondence: chlee915@korea.kr

2 Department of Fruit Science, Korea National College of Agriculture

and Fisheries, Jeonju 54874, Korea

Full list of author information is available at the end of the article
}

The composting reduced the volume of the manure wastes through the biochemical mineralization of the organic compound. The application of compost into soil could improve the soil fertility, provide nutrients, and minimize the risk of spreading pathogens and weeds [7-10]. Although composting is considered to have less environmental impact and wider applicability for various material [11], it inevitably emitted ammonia $\left(\mathrm{NH}_{3}\right)$ and greenhouse gas (GHG) such as carbon dioxide $\left(\mathrm{CO}_{2}\right)$, methane $\left(\mathrm{CH}_{4}\right)$ and nitrous oxide $\left(\mathrm{N}_{2} \mathrm{O}\right)$, which not only reduced the nutrients in final compost but weakened environmental benefits of composting [12]. During composting, carbon is mainly lost by $\mathrm{CO}_{2}$ and $\mathrm{CH}_{4}$ through $\mathrm{OM}$ mineralization and reduction of acetic acid and $\mathrm{CO}_{2}$. Nitrogen is lost through $\mathrm{NH}_{3}$ volatilization and $\mathrm{N}_{2} \mathrm{O}$ emission from nitrification and denitrification, as a result, there is a loss of nutrients and microbial degradation. Substantial discharges of 
$\mathrm{CO}_{2}, \mathrm{NH}_{3}, \mathrm{CH}_{4}$, and $\mathrm{N}_{2} \mathrm{O}$ occurred [13]. The amount and characteristics of gases produced from composting process vary widely, which is highly related to the initial materials and the composting methodology.

Recently, several researches evaluated the effect of different raw material such as garden waste, green waste material, compost bedding of dairy farm and pig manure on composting process and compost quality [14-18]. These studies collectively demonstrated that the compost materials and combination method among them will be steadily diversified which resulted in different composting process and final compost quality. Since chicken manure has high nitrogen and low moisture content, co-composting with chicken manure could favor microorganisms to degrade different organic solid wastes into qualified compost [19]. Moreover, co-composting could dispose two or more kind of organic wastes. However, little is known about the combination effect of chicken manure on composting process such gases emissions, nutrient content and maturity.

This study aims to characterize the co-composting process of chicken manure with organic wastes. The specific objectives of the present study were (1) to study changes in gases $\left(\mathrm{NH}_{3}, \mathrm{~N}_{2} \mathrm{O}, \mathrm{CO}_{2}, \mathrm{CH}_{4}\right)$ emissions during composting, (2) to investigate chemical characteristics of composts during composting, and (3) to assess relationship between gases emissions and compost quality.

\section{Materials and methods Composting materials}

The composts were prepared manually by mixing chicken manure with cattle manure, swine manure, crop residue and spent mushroom medium. Sawdust was used to regulate the initial moisture content of the raw material, and it was adjusted to about $60 \%$. The four treatments were labeled as OC (only chicken manure), $\mathrm{CC}$ (chicken + cow manure), CS (chicken + swine manure) and CRM (chicken manure + plant residue + spent medium), respectively. The detailed properties of raw materials are shown in Table 1.

\section{Experimental design}

The composting experiment was carried out using a conventional static chamber method for 107 days during winter-spring season. A plastic box $0.15 \mathrm{~m}^{3}$ in size $(0.65 \mathrm{~m} \times 0.44 \mathrm{~m} \times 0.51 \mathrm{~m})$ was used, which was covered with expanded polystyrene ( $5 \mathrm{~cm}$ thick) to prevent heat loss. The composting box was maintained open state during the experiment. The four treatments in this study were not replicated because the composting scale $(62 \mathrm{~L}$ of volume) ensures the experimental reproducibility as well evidenced in other studies [10,20,21]. Air was supplied from the bottom into the composting chamber with a constant air flow (1-1.5 $\left.\mathrm{L} \mathrm{min}{ }^{-1}\right)$, which was fixed with a flow meter. The internal temperature of pile was continuously monitored in the fields using a data logger (EM50 Data logger, USA).

Table 1 Properties of composting materials for this study (mean value \pm standard deviation from triplicate measurements)

\begin{tabular}{|c|c|c|c|c|c|c|}
\hline & Chicken & Cow & Swine & Chicken + residue & Spent medium & $\mathrm{LSD}_{0.05}$ \\
\hline $\mathrm{pH}$ & $7.09 \pm 0.01 d^{1}$ & $7.97 \pm 0.02 \mathrm{a}$ & $7.65 \pm 0.01 b$ & $6.82 \pm 0.01 e$ & $7.24 \pm 0.04 c$ & 0.041 \\
\hline$E C\left(d S m^{-1}\right)$ & $3.76 \pm 0.10 d$ & $4.45 \pm 0.02 b$ & $4.18 \pm 0.02 c$ & $4.75 \pm 0.03 a$ & $1.81 \pm 0.00 \mathrm{e}$ & 0.098 \\
\hline TC (\%) & $30.61 \pm 0.52 d$ & $35.32 \pm 0.23 b$ & $29.12 \pm 0.55 e$ & $32.53 \pm 0.16 c$ & $44.53 \pm 0.07 a$ & 0.660 \\
\hline TN (\%) & $5.81 \pm 0.19 a$ & $2.54 \pm 0.01 c$ & $2.88 \pm 0.01 b$ & $2.05 \pm 0.01 d$ & $1.65 \pm 0.05 e$ & 0.163 \\
\hline $\mathrm{C} / \mathrm{N}$ & $5.28 \pm 0.25 e$ & $13.89 \pm 0.05 c$ & $10.11 \pm 0.18 d$ & $15.84 \pm 0.19 b$ & $27.06 \pm 0.86 a$ & 0.762 \\
\hline TP (\%) & $16.89 \pm 1.32 \mathrm{a}$ & $8.66 \pm 1.01 b$ & $17.56 \pm 7.37 \mathrm{a}$ & $12.91 \pm 0.62 b$ & $6.07 \pm 2.22 b$ & 6.409 \\
\hline WEC $\left(\mathrm{g} \mathrm{kg}^{-1}\right)$ & $29.53 \pm 6.24 a$ & $18.77 \pm 0.55 b$ & $18.41 \pm 5.42 b$ & $31.01 \pm 6.69 a$ & $16.32 \pm 0.63 b$ & 8.154 \\
\hline WEN $\left(\mathrm{g} \mathrm{kg}^{-1}\right)$ & $6.08 \pm 1.15 a$ & $3.72 \pm 0.05 b$ & $3.66 \pm 0.99 b$ & $7.26 \pm 1.19 a$ & $3.32 \pm 0.21 b$ & 2.233 \\
\hline HWEC $\left(\mathrm{g} \mathrm{kg}^{-1}\right)$ & $14.54 \pm 0.27 a$ & $13.65 \pm 0.31 a$ & $13.75 \pm 0.31 \mathrm{a}$ & $11.30 \pm 0.26 b$ & $7.43 \pm 0.98 c$ & 2.155 \\
\hline HWEN $\left(\mathrm{g} \mathrm{kg}^{-1}\right)$ & $6.18 \pm 0.07 a$ & $2.67 \pm 0.04 b$ & $3.42 \pm 0.15 b$ & $2.97 \pm 0.03 b$ & $1.70 \pm 0.16 c$ & 2.411 \\
\hline $\mathrm{K}\left(\mathrm{mg} \mathrm{kg}^{-1}\right)$ & $20.61 \pm 0.58 b$ & $23.43 \pm 0.21 a$ & $22.80 \pm 0.47 a b$ & $17.74 \pm 1.02 c$ & $10.23 \pm 0.37 d$ & 1.567 \\
\hline $\mathrm{Ca}\left(\mathrm{mg} \mathrm{kg}^{-1}\right)$ & $41.55 \pm 6.37 a$ & $10.14 \pm 0.67 c$ & $34.83 \pm 2.51 \mathrm{ab}$ & $33.66 \pm 0.87 a b$ & $27.44 \pm 0.51 b c$ & 11.356 \\
\hline $\mathrm{Mg}\left(\mathrm{mg} \mathrm{kg}^{-1}\right)$ & $8.88 \pm 0.27 b$ & $7.23 \pm 0.14 c$ & $12.87 \pm 0.17 \mathrm{a}$ & $6.98 \pm 0.22 d$ & $4.49 \pm 0.22 d$ & 0.803 \\
\hline $\mathrm{Na}\left(\mathrm{mg} \mathrm{kg}^{-1}\right)$ & $3.73 \pm 0.11 c$ & $5.22 \pm 0.04 a b$ & $4.81 \pm 0.07 b$ & $6.98 \pm 0.01 a$ & $1.22 \pm 0.13 d$ & 0.367 \\
\hline
\end{tabular}

OC Only chicken manure, CC chicken + cow manure, CS chicken + swine manure, CRM chicken manure + plant residue + spent medium, $T C$ total carbon, $T N$ total nitrogen, TP total phosphorous, WEC and WEN water extractable carbon and water extractable nitrogen, HWEC and HWEN Hot-water extractable carbon and hot-water extractable nitrogen

1 Different letters in the same line indicate significant difference among treatments at $\mathrm{LSD}_{0.05}$ 


\section{Measurement and calculation of gases emission}

The closed chamber method was used to investigate flux of three greenhouse gases $\left(\mathrm{CO}_{2}, \mathrm{CH}_{4}\right.$ and $\left.\mathrm{N}_{2} \mathrm{O}\right)$ during the composting process [22]. The opaque chambers ( $\mathrm{D}$. $24 \mathrm{~cm}$ and $\mathrm{H} .20 \mathrm{~cm}$ ) was inserted into the compost pile to a depth of $15 \mathrm{~cm}$ only for sampling time. After sampling, these were removed and kept them next to compost reactor since every week compost piles should be turned and totally mixed to be properly homogenized and degraded. Gas samples were collected at 0 and $30 \mathrm{~min}$ after the chamber closure. Gases were sampled once a week and immediately transferred into air-evacuated vials $(20 \mathrm{~mL})$.

$\mathrm{NH}_{3}$ was absorbed by $0.1 \mathrm{~mol} \mathrm{~L}^{-1}$ sulfuric acid for quantification. The aqueous concentration of ammonia in the acid was analyzed by auto analyzer 3 (Bran Luebbe, Germany).

Gas $\left(\mathrm{NH}_{3}, \mathrm{CO}_{2}, \mathrm{~N}_{2} \mathrm{O}\right.$ and $\left.\mathrm{CH}_{4}\right)$ emission rate, $E_{a}$ ( $\mu \mathrm{g}$ dry $\mathrm{kg}^{-1} \mathrm{~h}^{-1}$ ) was calculated by Eq. (1) [22].

$$
\mathrm{E}_{\mathrm{a}}=\frac{C \times V}{M \times t}
$$

where $c$ is concentration of individual gas $\left(\mu \mathrm{g} \mathrm{m}^{-3}\right) ; V$ is the sum of the device and gas in a plastic composting box, $\left(\mathrm{m}^{3}\right) ; m$ is the initial weight of the composting material $(\mathrm{kg})$; and $t$ is sampling time, $\left(6\right.$ and $0.5 \mathrm{~h}$ for $\mathrm{NH}_{3}$ and other gases in this study).

The concentrations of $\mathrm{CO}_{2}, \mathrm{CH}_{4}$ and $\mathrm{N}_{2} \mathrm{O}$ were analyzed using gas chromatography (Shimadzu, GC-2010, Tokyo). Total fluxes of gases were calculated on an initial mass basis during composting process $\left(\mathrm{g} \mathrm{m}^{-2}\right)[23,24]$.

$$
\text { Total } \mathrm{NH}_{3}, \mathrm{CO}_{2}, \mathrm{CH}_{4} \text { or } \mathrm{N}_{2} \mathrm{O} \text { flux }=\Sigma_{i}^{\mathrm{n}}\left(\mathrm{R}_{i} \times \mathrm{D}_{i}\right)
$$

where ' $n$ ' is the number of sampling intervals, $R_{i}$ is the gas emissions rate $\left(\mathrm{mg}^{-2} \mathrm{day}^{-1}\right)$ in the $i$ th sampling interval and $\mathrm{D}_{i}$ : the number of days in the $i$ th sampling interval.

\section{Analytic methods}

Once a week, compost piles were turned and thoroughly mixed. After mixing, compost samples were collected using sampling core (diameter $5 \mathrm{~cm} \times$ height $5 \mathrm{~cm}$ ) at three different points (10-20 cm depth of compost pile). Fresh solid samples were dried at $65^{\circ} \mathrm{C}$ for approximately $48 \mathrm{~h}$ and ground and sieved with $2 \mathrm{~mm}$ for chemical analysis. The total $\mathrm{C}$ and $\mathrm{N}$ concentration were analyzed by an elemental analyzer (CHNS-932 Analyzer, Leco.). The water extractable carbon (WEC), nitrogen (WEN) and hot-water extractable carbon (HWEC), nitrogen (HWEN), relatively labile organic compounds, were extracted by distilled water. The concentration was determined by TOC-5050A analyzer (Shimadzu Corporation, Japan). The nutrient ( $\mathrm{P}, \mathrm{K}, \mathrm{Ca}, \mathrm{Mg}, \mathrm{Na}$ ) contents were determined from digested samples using ternary solution $\left(\mathrm{HNO}_{3}: \mathrm{H}_{2} \mathrm{SO}_{4}: \mathrm{HClO}_{4}=10: 1: 4, \mathrm{v} / \mathrm{v} / \mathrm{v}\right)$ by spectrometry (ICP, Agilent) [25].

The compost samples were mixed with distilled water $(1: 20 \mathrm{w} / \mathrm{w}$ ratio) and shaken for $2 \mathrm{~h}$. The $\mathrm{pH}$ and EC values were determined (Orion 3star, Thermo Electron Corporation, MA, USA). The extract was filtered through a $5 \mu \mathrm{m}$ filter paper to evaluate the germination index (GI). The phytotoxicity and maturity level of compost pile were assessed by GI value [26]. Thirty radish seeds were distributed on filter paper in petri dishes ( $85 \mathrm{~mm}$ in diameter) and moistened with $5 \mathrm{~mL}$ of the compost water extract. Distilled water was used as a control. Three replicate for each sample were incubated at $25{ }^{\circ} \mathrm{C}$, and the number of germinating seeds were counted after $72 \mathrm{~h}$. They were again incubated and root length was measured between 120 and $125 \mathrm{~h}$ of incubation. The GI value was calculated by the following formula:

GI (\%)

$$
=\frac{[\text { Seed germination of treatment }][\text { Root length of treatment }]}{[\text { Seed germination of control }][\text { Root length of control }]}
$$

Mean values and standard deviations of triplicate measurements were shown in this study. The data were subjected to one-way analysis of variance (ANOVA), and identified the least significance variance (LSD) at $P=0.05$ values by Statistical Analysis System (SAS 8.2). Determination of differences between parameters was performed via two-way ANOVA that included composting effect (initial and final compost product), treatment (different raw materials) and their interaction. The correlation coefficients were calculated using $\mathrm{R}$ software to determine the linear relationship between gases emissions and compost properties.

\section{Result and discussion $\mathrm{CO}_{2}$ and $\mathrm{CH}_{4}$ emission}

The $\mathrm{CO}_{2}$ emission (Fig. 1) certainly presented the overall microbial activities and influenced the composting efficiency or degradation of organic matter [27, 28]. The $\mathrm{CO}_{2}$ emission was rapidly increased within the first few days in all treatments, the maximum $\mathrm{CO}_{2}$ emission 1574 (14th day), 1239 (7th day), 1385 (77th day) and 1016 (7th day) $\mathrm{g} \mathrm{kg}^{-1}$ day $^{-1}$ were observed in OC, $\mathrm{CC}, \mathrm{CS}$ and CRM, respectively. Then $\mathrm{CO}_{2}$ emission was gradually decreased and dropped till the bottom after 30th day, then finally maturation phase was attributed with lowest $\mathrm{CO}_{2}$ emission. It indicated the stability of the end product or compost. $\mathrm{CO}_{2}$ emission trend is very similar with variation of temperature, and highly positive correlation was found between them (Table 2). The initial increasing trend of $\mathrm{CO}_{2}$ is because of rapid 


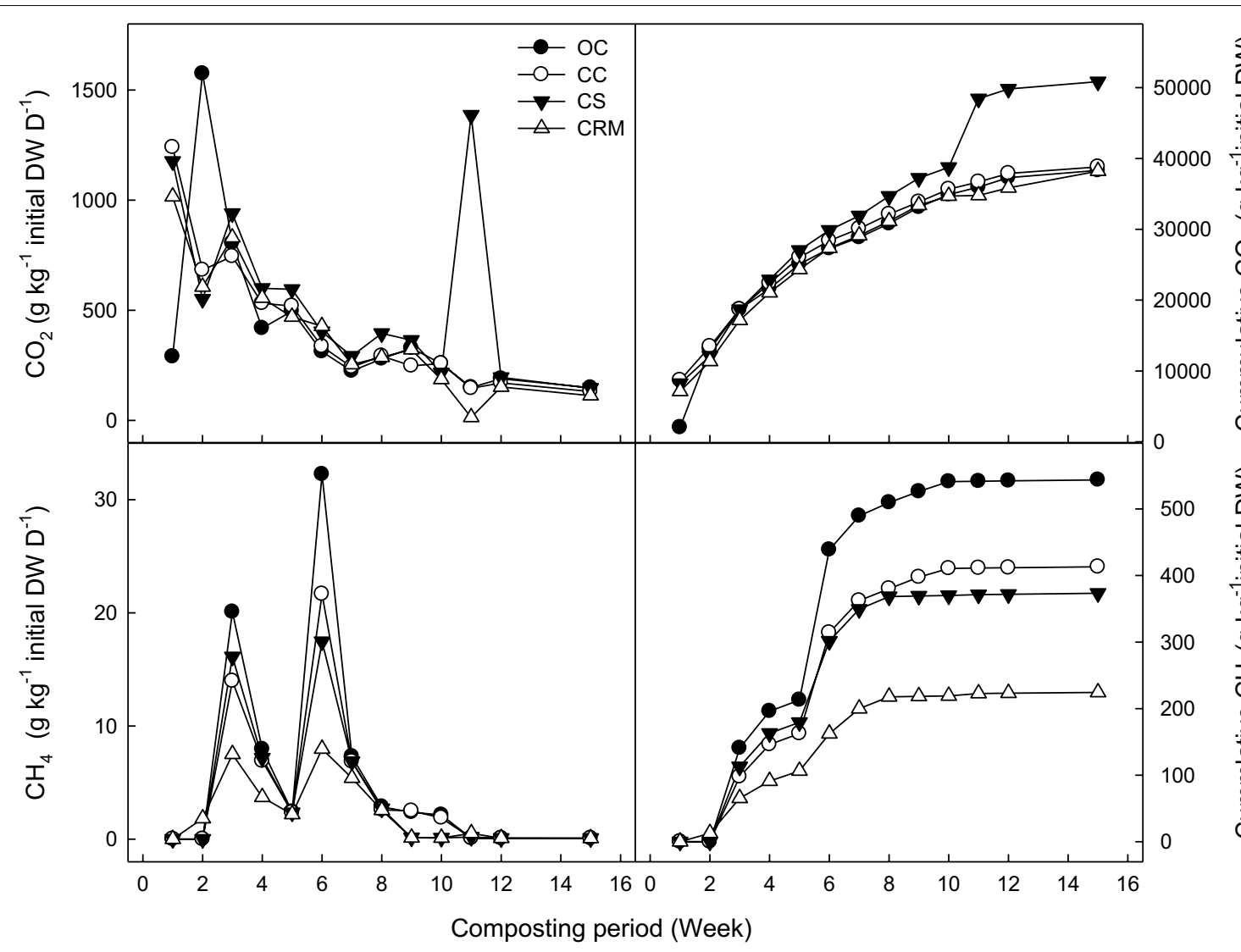

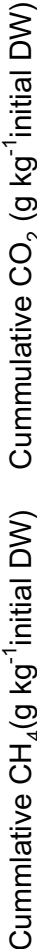

Fig. 1 Emission rates and cumulative emissions of carbon dioxide $\left(\mathrm{CO}_{2}\right)$ and methane $\left(\mathrm{CH}_{4}\right)$ during composting. OC Only chicken manure, $\mathrm{CC}$ chicken + cow manure, CS chicken + swine manure, CRM chicken manure + plant residue + spent medium

Table 2 Correlation coefficient ( $P$ value) between gases emissions and compost properties

\begin{tabular}{|c|c|c|c|c|c|c|c|c|c|c|c|}
\hline Parameter & $\mathrm{NH}_{3}$ & $\mathrm{~N}_{2} \mathrm{O}$ & $\mathrm{CO}_{2}$ & $\mathrm{CH}_{4}$ & Temperature & $\mathrm{pH}$ & C & $\mathrm{N}$ & $\mathrm{C} / \mathrm{N}$ & $\mathrm{NO}_{3}$ & $\mathrm{NH}_{4}$ \\
\hline $\mathrm{NH}_{3}$ & 1.000 & & & & & & & & & & \\
\hline $\mathrm{N}_{2} \mathrm{O}$ & $0.006^{* *}$ & 1.000 & & & & & & & & & \\
\hline $\mathrm{CO}_{2}$ & $0.005^{* *}$ & $<0.001^{* * *}$ & 1.000 & & & & & & & & \\
\hline $\mathrm{CH}_{4}$ & 0.763 & $0.021^{*}$ & 0.656 & 1.000 & & & & & & & \\
\hline Temperature & $0.007^{* *}$ & $<0.001^{* * *}$ & $<0.001^{* * *}$ & 0.386 & 1.000 & & & & & & \\
\hline $\mathrm{pH}$ & 0.401 & 0.133 & 0.074 & 0.216 & 0.235 & 1.000 & & & & & \\
\hline C & 0.217 & 0.189 & 0.111 & 0.814 & $0.016^{*}$ & $0.017^{*}$ & 1.000 & & & & \\
\hline$N$ & $<0.001^{* * *}$ & 0.947 & 0.855 & 0.110 & 0.985 & $0.047^{*}$ & $<0.001^{* * *}$ & 1.000 & & & \\
\hline $\mathrm{C} / \mathrm{N}$ & $<0.001^{* * *}$ & 0.503 & 0.511 & 0.201 & 0.464 & 0.116 & $0.005^{* *}$ & $<0.001^{* * *}$ & 1.000 & & \\
\hline $\mathrm{NO}_{3}$ & 0.121 & 0.007 & $0.042^{*}$ & 0.157 & $0.002^{* *}$ & 0.181 & $0.029^{*}$ & 0.659 & 0.988 & 1.000 & \\
\hline $\mathrm{NH}_{4}$ & 0.240 & 0.495 & 0.102 & 0.398 & $0.039^{*}$ & 0.751 & $0.004^{* *}$ & 0.190 & 0.275 & 0.442 & 1.000 \\
\hline
\end{tabular}

$*{ }^{* * *}$, and ${ }^{* * *}$ denote significance at the 5,1 , and $0.1 \%$ levels, respectively

degradation of organic matter under high temperatures. But CS treatment showed high peak of $\mathrm{CO}_{2}$ at both initial and late stages, which reached highest $\mathrm{CO}_{2}$ flux $\left(52 \mathrm{~kg} \mathrm{~kg} \mathrm{dw}^{-1}\right)$ while other treatments have similar $\mathrm{CO}_{2}$ flux values $\left(38-40 \mathrm{~kg} \mathrm{~kg} \mathrm{dw}^{-1}\right)$.
Methane was produced by methanogen using $\mathrm{CO}_{2}$ and acetic acid in anaerobic condition. Higher emission of $\mathrm{CH}_{4}$ could be indicated the unsuitable aeration during composting and improper density between raw materials [9]. Overall, low mean $\mathrm{CH}_{4}$ emissions were 
recorded. The emission patterns indicated that the anaerobic condition caused similar $\mathrm{CH}_{4}$ emission pattern, but concentration was different among the treatments. The $\mathrm{CH}_{4}$ emission increased within the 50 days (thermophilic and mesophilic phase) and then gradually decreased to an undetectable level for all treatment. The initially increased $\mathrm{CH}_{4}$ emission might be due to the largely consumed oxygen for organic matter decomposition during the thermophilic beginning phase. The highest accumulated $\mathrm{CH}_{4}$ was observed in $\mathrm{OC}$, and its peak value was reached on the 42 th day $\left(32 \mathrm{~g} \mathrm{~kg}^{-1}\right.$ initial matter day ${ }^{-1}$ ).

Microorganisms can rapidly degrade organic component, causing the consumption of oxygen supplied by aeration system in the thermophilic phase $[29,30]$.

\section{$\mathrm{NH}_{3}$ and $\mathrm{N}_{2} \mathrm{O}$ emission}

The changes in $\mathrm{NH}_{3}$ emission rates are shown in Fig. 2. The ammonia was emitted accompanied by the decomposition of $\mathrm{N}$ organic material during the early thermophilic phase. It happened because the compost reached the thermophilic stage and the organic acid began to volatilize rapidly in early stage (Fig. 2). This observation is different from that reported by Yang et al. [31], perhaps due to lower $\mathrm{N}$ content in food waste compared to chicken manure. After high peaks of ammonia volatilization, $\mathrm{NH}_{3}$ content of all treatments slightly declined between 4th and 5th week of composting, and then promptly elevated and finally stabilized. In this study, $40-75 \%$ of $\mathrm{NH}_{3}$ flux was emitted at initial stages (5th week of 15 th week). These results agreed with the emission pattern previously described by Sommer [32], El Kader et al. [33], Ahn et al. [34], and Wang and Zheng [35]. Mixing with swine manure (CS) or plant residue plus spent mushroom medium (CRM) increased $\mathrm{NH}_{3}$ emission by 4.1 times compared with only chicken manure (OC). It is assumed that because of expended thermophilic phase and increased $\mathrm{NH}_{4}-\mathrm{N}$ content in both CS and CRM treatments (Fig. 3). Combination with cow manure was most effective to mitigate $\mathrm{NH}_{3}$ emission, only chicken manure as well. Reduced $\mathrm{NH}_{3}$ emission might improve nutrient of compost. It indicated that selection of combination materials could be a good practice to compost quality.

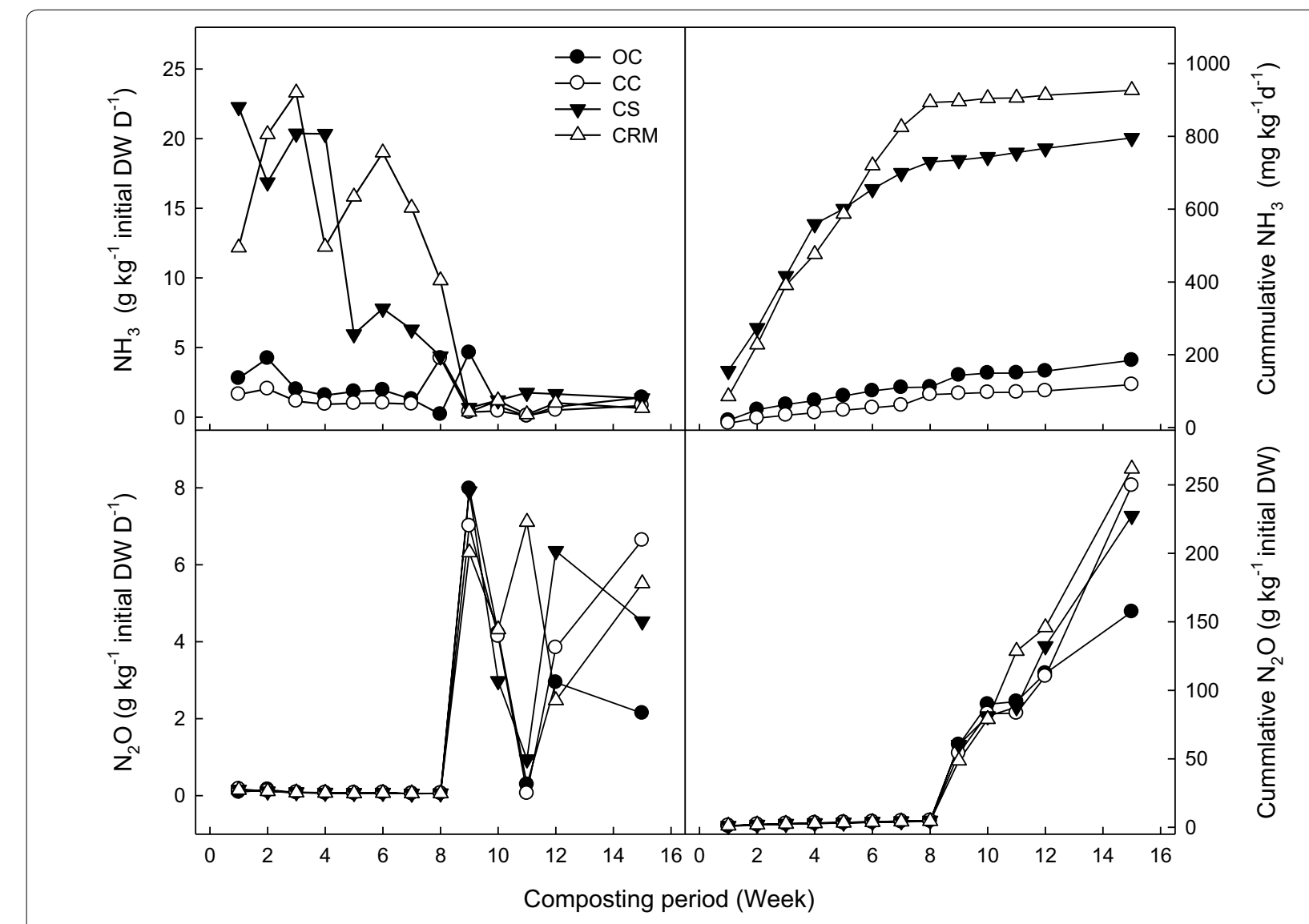

Fig. 2 Emission rates and cumulative emissions of ammonia $\left(\mathrm{NH}_{3}\right)$ and nitrous oxide $\left(\mathrm{N}_{2} \mathrm{O}\right)$ during composting. OC Only chicken manure, $\mathrm{CC}$ chicken + cow manure, CS chicken + swine manure, CRM chicken manure + plant residue + spent medium 
As shown in Fig. 2, $\mathrm{N}_{2} \mathrm{O}$ emission was observed after 60 days of composting in most of the treatments. Until middle of composting period, the conversion from organic nitrogen to $\mathrm{NH}_{4}{ }^{+}-\mathrm{N}$ was the dominant process, therefore the $\mathrm{N}_{2} \mathrm{O}$ emissions was not negligible. A low $\mathrm{NO}_{3}-\mathrm{N}$ concentration at beginning stage which is insufficient to emit $\mathrm{N}_{2} \mathrm{O}$ through denitrification during the thermophilic beginning phase. It might be due to incomplete denitrification/nitrification processes that change $\mathrm{NH}_{4}{ }^{+}$into $\mathrm{N}$ gas [31,33]. Conflicting with that result, some researcher reported that a high concentration of $\mathrm{N}_{2} \mathrm{O}$ was found at the initial stage of composting period $[28,34]$. In our study, except $\mathrm{N}_{2} \mathrm{O}$ emission, all the gases were increased from beginning of the experiment. It might be adjusted suitable conditions of compost pile such as $50-60 \%$ of moisture content and $<25$ of $\mathrm{CN}$ ratio that can rapidly degrade organic matters.

Nitrous oxide emission rapidly accelerated during the mesophilic and cooling phase, which is closely related with Han et al. [36] observation, who found that if the composting period was extended, $\mathrm{N}_{2} \mathrm{O}$ emissions during the cooling phase may have overran the mesophilic phase. Thus, temperature can be a major factor for controlling $\mathrm{N}_{2} \mathrm{O}$ emission during aerobic composting of chicken manure $(P<0.001)$ (Table 2$)$.

\section{Changes in temperature, $\mathrm{pH}$ and content of $\mathrm{NO}_{3}$ and $\mathrm{NH}_{4}$}

The compost pile temperature is determined by the balance between heat production by organic matter degradation and heat dissipation of the pile [37]. Figure 3 showed consistent patterns with thermophilic, mesophilic and maturation stages in all four treatments. All treatments' temperature rapidly rose, with temperatures above $60{ }^{\circ} \mathrm{C}$ at the initial stage, presented an appropriate initial ratio of compost [38]. The combination of chicken manure with other manure and residues might be favorable to microbial activity that produces heat. In the thermophilic phase, the temperature of all piles remained above $54{ }^{\circ} \mathrm{C}$ for $6-8$ days, which secured reduction of pathogens to satisfy the maturity and sanitation requirements. The CS treatment had longer thermophilic phase. Huang et al. [39] observed that swine manure had the least $\mathrm{O}$-alkyls and anomeric of carbohydrates, and thus it was more resistant to microbial attacks. The OC

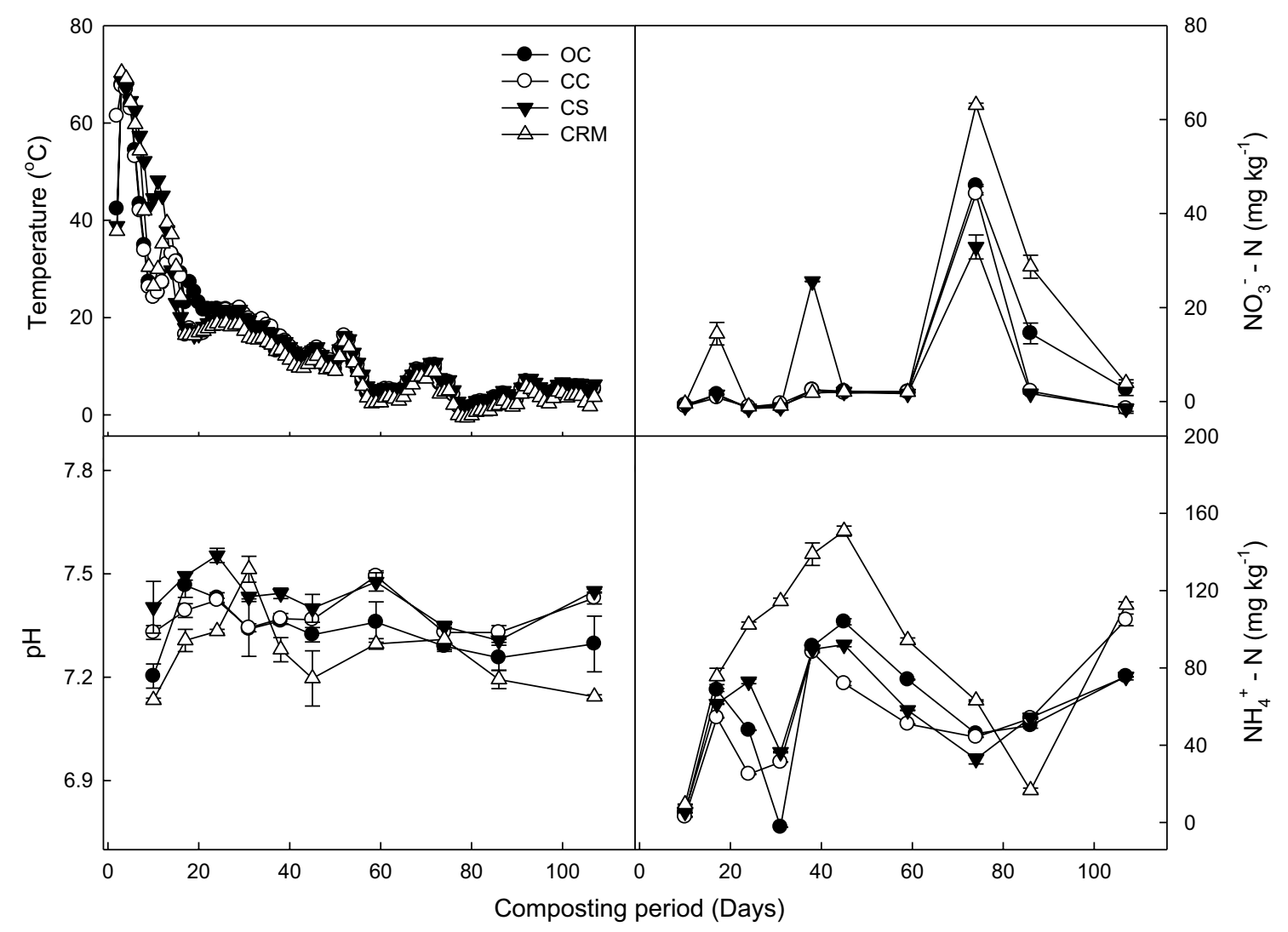

Fig. 3 Changes in temperature, $\mathrm{pH}, \mathrm{NO}_{3}{ }^{-} \mathrm{N}$ and $\mathrm{NH}_{4}{ }^{+}-\mathrm{N}$ of compost pile during composting. Values are the average of three repeats and error bars indicates the standard deviation. OC Only chicken manure, CC chicken + cow manure, CS chicken + swine manure, CRM chicken manure + plant residue + spent medium 
treatment most rapidly reached over $60{ }^{\circ} \mathrm{C}$ just 2 days after composting. It could be because of the highest concentration of water extractable $\mathrm{C}$ and $\mathrm{N}$ and hot-water extractable $\mathrm{C}$ and $\mathrm{N}$ in chicken manure, which is easily used for microbial (Table 1).

Although $\mathrm{pH}$ is an indicator for state of composing, $\mathrm{pH}$ values in all treatments showed a similar trend with small changes. Increasing trend in the thermophilic phase were found. That trend could be attributed to the degradation of acid compounds and the increase of ammonia.

The nitrogen is firstly converted into $\mathrm{NH}_{4}{ }^{+}-\mathrm{N}$ and easily volatilized as $\mathrm{NH}_{3}$ in the thermophilic stage, due to the high temperature and slightly alkaline condition resulted from the decomposition of compost. The $\mathrm{NH}_{4}{ }^{+}-\mathrm{N}$ is converted into $\mathrm{NO}_{3}{ }^{-} \mathrm{N}$ through aerobic nitrification and anaerobic denitrification, during which the $\mathrm{N}_{2} \mathrm{O}$ and $\mathrm{N}_{2}$ produced. The $\mathrm{NO}_{3}{ }^{-}-\mathrm{N}$ concentration was low at the initial stage of the composting and increased sharply in the second mesophilic/maturation phase.

\section{Changes in compost quality}

Table 3 shows the concentration of carbon (C), nitrogen $(\mathrm{N}), \mathrm{C} / \mathrm{N}$ ratio, phosphorus $(\mathrm{P})$, calcium $(\mathrm{Ca})$, magnesium $(\mathrm{Mg})$, potassium $(\mathrm{K})$, sodium $(\mathrm{Na})$, electricity productivity (EC) and $\mathrm{pH}$ in all treatment at initial (0 week) and final (15 week) stages. Composting cycle significantly increased $\mathrm{C} / \mathrm{N}$ ratio, $\mathrm{P}, \mathrm{Ca}, \mathrm{Mg}, \mathrm{K}, \mathrm{Na}, \mathrm{EC}$ and $\mathrm{pH}$, specially Ca content of final compost was greatly increased by 1.4-3.0 times over that of initial compost $(P<0.001)$. Total $\mathrm{N}$ concentration was decreased by $20-31 \%$ at final stage except CC treatment, where emitted the lowest $\mathrm{NH}_{3}$. Only total $\mathrm{C}$ and $\mathrm{Ca}$ concentration was not affected by composting process, while other properties were considerably changed by composting process. Total carbon concentration slightly increased despite carbon losses. This might be due to the influence of sawdust used as a bulking agent. Considering the total mass reduction, total $\mathrm{C}$ of compost definitely decreased as shown in Table 4. The compost types showed significant difference in all parameters analyzed $(P<0.001)$ (Table 3$)$.

$\mathrm{C} / \mathrm{N}$ ratio is main indicator to present the stability of composting and the maturity of final product [29]. Similar with previous studies $[40,41]$, the $\mathrm{C} / \mathrm{N}$ ratio slightly increased at thermophilic stage, it might be due to the $\mathrm{N}$ loss caused by ammonia volatilization. The final $\mathrm{C} / \mathrm{N}$ ratio values of four treatments were less than 25 , which is indicated the maturity (Fig. 4).

The EC of all treatments increased at the beginning of the composting process due to the decomposition of complex organic matters into dissolved components $[42,43]$. Slightly higher EC value was observed in CC treatment than others. The EC values in final products of all treatments OC, CC, CS and CRM were 3.21, 3.93, 3.62 and 3.17 , respectively (data graph was not shown). Awasthi et al. [9] previously reported that less than $4 \mathrm{dS} \mathrm{m}^{-1}$ of EC value will not cause any phytotoxicity to apply. Thus, the final compost product of all treatments were allowed for non-phytotoxic limit.

Table 4 Carbon and nitrogen balances during composting

\begin{tabular}{llllcc}
\hline Treatment & \multicolumn{2}{c}{ Carbon balance (\%) } & & \multicolumn{2}{c}{ Nitrogen balance (\%) } \\
\cline { 2 - 3 } \cline { 6 - 6 } & $\mathbf{C O}_{\mathbf{2}}-\mathbf{C}$ & $\mathbf{C H}_{\mathbf{4}} \mathbf{- C}$ & & $\mathbf{N}_{\mathbf{2}} \mathbf{O}-\mathbf{N}$ & $\mathbf{N H}_{\mathbf{3}}-\mathbf{N}$ \\
\hline $\mathrm{OC}$ & 57.5 & 2.2 & 9.2 & 12.3 \\
$\mathrm{CC}$ & 58.2 & 1.7 & 11.3 & 6.9 \\
$\mathrm{CS}$ & 76.2 & 1.5 & 11.8 & 52.3 \\
$\mathrm{CRM}$ & 54.9 & 0.9 & & 13.3 & 65.4 \\
\hline
\end{tabular}

OC Only chicken manure, CC chicken + cow manure, CS chicken + swine manure, CRM chicken manure + plant residue + spent medium

Table 3 Characteristics of initial and final compost (mean value \pm standard deviation from triplicate measurements)

\begin{tabular}{|c|c|c|c|c|c|c|c|c|c|c|c|}
\hline \multirow{2}{*}{$\begin{array}{l}\text { Composting cycle (A) } \\
\text { Compost (B) }\end{array}$} & \multicolumn{4}{|c|}{ Initial (0 week) } & \multicolumn{4}{|c|}{ Final (15 week) } & \multicolumn{3}{|c|}{ LSD ( $P$ value) } \\
\hline & OC & $\mathrm{CC}$ & CS & CRM & OC & $\mathrm{CC}$ & CS & CRM & A & B & $A \times B$ \\
\hline TC (\%) & $35 \pm 0.3$ & $37 \pm 0.5$ & $37 \pm 0.3$ & $35 \pm 0.3$ & $38 \pm 0.7$ & $40 \pm 0.9$ & $39 \pm 1.3$ & $35 \pm 0.9$ & 0.076 & $<0.001$ & $<0.001$ \\
\hline TN (\%) & $2.6 \pm 0.1$ & $1.5 \pm 0.1$ & $2.5 \pm 0.2$ & $3.4 \pm 0.01$ & $1.8 \pm 0.03$ & $1.7 \pm 0.09$ & $2.0 \pm 0.2$ & $2.4 \pm 0.1$ & 0.009 & $<0.001$ & $<0.001$ \\
\hline $\mathrm{C} / \mathrm{N}$ & $13.8 \pm 0.5$ & $24.7 \pm 1.4$ & $14.9 \pm 1.0$ & $10.3 \pm 0.1$ & $20.5 \pm 0.2$ & $20.9 \pm 0.6$ & $16.6 \pm 1.5$ & $15.7 \pm 2.0$ & 0.016 & $<0.001$ & $<0.001$ \\
\hline TP (\%) & $10.3 \pm 0.3$ & $6.7 \pm 1.6$ & $10.3 \pm 1.7$ & $10.2 \pm 0.4$ & $11.3 \pm 0.5$ & $10.29 \pm 0.3$ & $13.4 \pm 0.9$ & $11.6 \pm 1.6$ & 0.009 & $<0.001$ & 0.004 \\
\hline $\mathrm{Ca}\left(\mathrm{mg} \mathrm{kg}^{-1}\right)$ & $25.6 \pm 0.5$ & $26.3 \pm 1.9$ & $28.4 \pm 1.8$ & $48.9 \pm 3.3$ & $76.7 \pm 7.6$ & $51.8 \pm 3.0$ & $60.1 \pm 4.9$ & $67.0 \pm 6.2$ & 0.029 & $<0.001$ & 0.002 \\
\hline$M g\left(\mathrm{mg} \mathrm{kg}^{-1}\right)$ & $6.4 \pm 0.1$ & $4.5 \pm 0.2$ & $6.1 \pm 0.2$ & $10.2 \pm 0.2$ & $11.5 \pm 0.8$ & $10.0 \pm 0.5$ & $11.8 \pm 0.5$ & $12.3 \pm 1.1$ & 0.012 & 0.013 & 0.033 \\
\hline $\mathrm{K}\left(\mathrm{mg} \mathrm{kg}^{-1}\right)$ & $13.9 \pm 0.8$ & $11.9 \pm 1.1$ & $12.9 \pm 0.6$ & $9.7 \pm 0.1$ & $14.4 \pm 0.9$ & $18.9 \pm 0.2$ & $17.4 \pm 0.8$ & $12.4 \pm 0.3$ & 0.010 & $<0.001$ & 0.056 \\
\hline $\mathrm{Na}\left(\mathrm{mg} \mathrm{kg}^{-1}\right)$ & $2.4 \pm 0.1$ & $2.6 \pm 0.2$ & $2.6 \pm 0.1$ & $4.9 \pm 0.1$ & $4.8 \pm 0.4$ & $6.2 \pm 0.2$ & $5.2 \pm 0.3$ & $7.1 \pm 0.5$ & 0.008 & $<0.001$ & 0.095 \\
\hline $\mathrm{EC}\left(\mathrm{dS} \mathrm{m}^{-1}\right)$ & $2.8 \pm 0.02$ & $2.8 \pm 0.03$ & $2.9 \pm 0.08$ & $2.6 \pm 0.02$ & $3.2 \pm 0.04$ & $3.9 \pm 0.07$ & $3.6 \pm 0.21$ & $3.2 \pm 0.06$ & 0.002 & $<0.001$ & $<0.001$ \\
\hline $\mathrm{pH}\left(1: 10 \mathrm{H}_{2} \mathrm{O}\right)$ & $7.1 \pm 0.02$ & $7.4 \pm 0.01$ & $7.2 \pm 0.01$ & $6.8 \pm 0.01$ & $7.3 \pm 0.08$ & $7.3 \pm 0.02$ & $7.3 \pm 0.01$ & $7.2 \pm 0.01$ & 0.010 & $<0.001$ & 0.001 \\
\hline
\end{tabular}




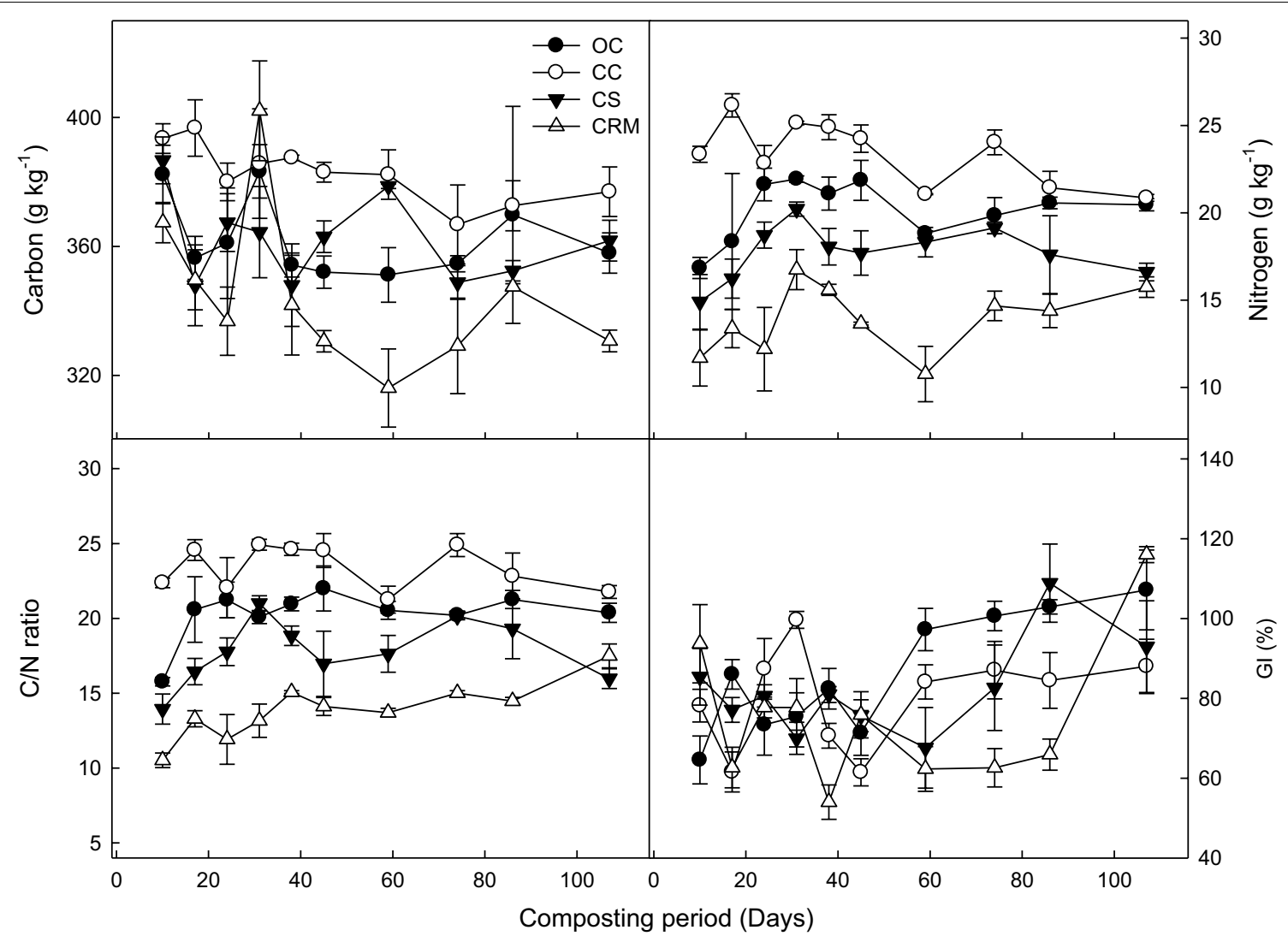

Fig. 4 Changes in carbon, nitrogen, $\mathrm{C} / \mathrm{N}$ ratio and germination index (GI) of compost pile during composting. Values are the average of three repeats and error bars indicates the standard deviation. OC Only chicken manure, CC chicken + cow manure, CS chicken + swine manure, CRM chicken manure + plant residue + spent medium

The GI values gradually increased with composting in all treatments (Fig. 4). This changes of GI were similar with previous studies [44, 45]. A more rapid increase in GI was found in OC and CC treatments, whose GI reached and maintained above $80 \%$ from 60 days of composting. It might be attributed to relatively low $\mathrm{NH}_{3}$ emission during whole composting period. At the final stage, GI values attained more than $80 \%$, indicating the maturity of compost in all treatments [46]. Thus all four composts could be safely applied in agricultural soil without any phytotoxic effects.

The present study indicates the importance of co-composting material to control gases emissions and compost quality during chicken manure composting. The chicken manure had the greatest amount of labile organic matter such as WEC, WEN, HWEC and HWEN. Therefore, OC treatment most rapidly reached the highest temperature immediately after composting and, showed the highest $\mathrm{CO}_{2}$ emission at beginning of composting. Mixing this chicken manure with other organic wastes brought different carbon and nitrogen losses. The CS and CRM exhibited relatively longer thermophilic phase, which leaded degradation of acid type compound and increase in $\mathrm{NH}_{3}$. On the other hand, $\mathrm{CC}$ treatment didn't show specific increases in gases emissions. The OC and CC showed slightly faster maturation, it should be due to the smaller amount of $\mathrm{NH}_{3}$ generated in $\mathrm{OC}$ and $\mathrm{CC}$ than that in CS and CRM. Our findings suggest that sole chicken manure or combination with cow manure could be effective strategy to improve compost quality and minimize gases losses for chicken manure composting.

\section{Acknowledgements}

This study was supported by Rural Development Administration (PJ01346801), Republic of Korea.

\section{Authors' contributions}

CHL, SJP and MSK designed the experiments. $\mathrm{HYH}$ and $\mathrm{CHL}$ conducted the field research, analyzed and process data. SHK, SJP and MSK reviewed the results from the study and supervised the whole project. HYH and SHK wrote the manuscript. All authors read and approved the final manuscript.

\section{Funding}

No funding was received. 


\section{Availability of data and materials}

The datasets supporting the conclusions of this study are including within this manuscript.

\section{Competing interests}

The authors declare that they have no competing interests.

\section{Author details}

${ }^{1}$ Soil and Fertilizer Division, National Institute of Agricultural Sciences, RDA, Wanju 55365, Korea. ${ }^{2}$ Department of Fruit Science, Korea National College of Agriculture and Fisheries, Jeonju 54874, Korea.

Received: 13 November 2019 Accepted: 11 December 2019

Published online: 08 January 2020

\section{References}

1. Gerber PJ, Steinfeld H, Henderson B, Mottet A, Opio C, Dijkman J, Falcucci A, Tempio G (2013) Tackling climate change through livestock a global assessment of emissions and mitigation opportunities. Food and Agriculture Organization of the United Nations (FAO), Rome

2. Won S, Ahmed N, You BG, Shim S, Kim SS, Ra C (2018) Nutrient production from Korean poultry and loading estimations for cropland. J Anim Sci Technol 60:3

3. KOSIS (Korean Statistical Information Service). 2015. http://kosis.kr/eng/stati sticsList/statisticsList_01List.jsp?vwcd=MT_ETITLE\&parentld=A Accessed 9 Apr 2015

4. Nyamangara J, Gotosa J, Mpofu SE (2001) Cattle manure effect on structural stability and water relation capacity of granitic soil in Zimbabwe. Soil Tillage Res 62:157-162

5. Hepperly P, Lotter D, Ulsh CZ, Reider C (2009) Compost, manure and synthetic fertilizer influences crop yields, soil properties, nitrate leaching and crop nutrient content. Compost Sci Util 17:117-126

6. Salazar FJ, Chadwick D, Pain BF, Hatjch D, Owen E (2005) Nitrogen budgets for three cropping systems fertilized with cattle manure. Bioresour Technol 96:235-245

7. Larney FJ, Hao X (2007) A review of composting as a manargment alternative for beef cattle feedlot manure in southern Alberta, Canada. Bioresour Technol 98:3221-3227

8. Carr L, Grover R, Smith B, Richard T, Halbach T (1995) Commercial and on-farm production and marketing of animal waste compost products. In: Steele K (ed) Animal waste and the land water interface. Lewis Publishers, Boca Raton, pp 485-492

9. Awasthi MK, Pandey AK, Bundela PS, Wong JWC, Li R, Zhang Z (2016) Cocomposting of gelatin industry sludge combined with organic fraction of municipal solid waste and poultry waste employing zeolite mixed with enriched nitrifying bacterial consortium. Bioresour Technol 213:181-189

10. Zhang H, Li G, Gu J, Wang G, Li Y, Zhang D (2016) Influence of aeration on volatile sulfur compounds (VSCs) and $\mathrm{NH}_{3}$ emissions during aerobic composting of kitchen waste. Waste Manag 58:369-375

11. Saer A, Lansing S, Davitt N (2013) Life cycle assessment of a food waste composting system: environmental impact hotpots. J Clean Prod 52:234-244

12. Crutzen PJ (1970) The influence of nitrogen oxides on the atmospheric ozone content. Q J R Meteorol Soc 96(408):320-325

13. Yuan J, Chadwick D, Zhang D, Li G, Chen S, Luo W, Du L, He S, Peng S (2016) Effect of aeration rate on maturity and gaseous emissions during sewage sludge composting. Waste Manag 56:403-410

14. Xia ZB, Sshannon KB, Kyaw TPU, Martin B, William RH (2017) Greenhouse gas emissions from green waste composting window. Waste Manag 59:70-79

15. Arriaga H, Viguria M, Lopez DM, Merino P (2017) Ammonia and greenhouse gases losses from mechanically turned cattle manure windrows: a regional composting network. J Environ Manag 203(1):557-563

16. Jiang T, Schuchardt F, Li G, Guo R, Zhao Y (2011) Effect of C/N ratio, aeration rate and moisture content on ammonia and greenhouse gas emission during the composting. J Environ Sci 23(10):1754-1760

17. Fillingham MA, Vanderzaag AC, Burtt S, Balde H, Ngwabie NM, Smith W, Hakami A, Wagner-Riddle C, Bitteman S, Macdonald D (2017) Greenhouse gas and ammonia emissions from production of compost bedding on a dairy farm. Waste Manag 70:45-52
18. Zeng J, Yin H, Shen X, Liu N, Ge J, Han L, Huang G (2018) Effect of aeration internal on oxygen consumption and GHG emission during pig manure composting. Bioresour Technol 250:214-220

19. Preusch PL, Adler PR, Sikora LJ, Tworkoski TJ (2002) Nitrogen and phosphorus availability in composted and uncomposted poultry litter. J Environ Qual 31:2051-2057

20. Yuan J, Yang Q, Zhang Z, Li G, Luo W, Zhang D (2015) Use of additive and pretreatment to control odors in municipal kitchen waste during aerobic composting. J Environ Sci 37:83-90

21. Jiang T, Ma X, Yang J, Tang Q, Yi Z, Chen M, Li G (2016) Effect of different struvite crystallization methods on gaseous emission and the comprehensive comparison during the composting. Bioresour Technol 217:219-226

22. Han Z, Sun D, Wang H, Li R, Bao Z, Qi F (2018) Effects of ambient temperature and aeration frequency on emissions of ammonia and greenhouse gases from a sewage sludge aerobic composting plant. Bioresour Technol 270:457-466

23. Singh S, Singh JS, Kashyap AK (1999) Methane flux from irrigated rice fields in relation to crop growth and $\mathrm{N}$ fertilization. Soil Biol Biochem 31:1219-1228

24. Robertson GP, Paul E, Harwood R (2000) Greenhouse gases in intensive agriculture: contributions of individual gases to the radiative forcing of the atmosphere. Science 289:1922-1925

25. Yoshida S, Forno DA, Cock JH, Gomez KA (1976) Routine procedure for growing rice plants in culture solution. Laboratory manual for physiological studies in rice, 3rd edn. International Rice Research Institute, Manila, pp 61-66

26. RDA (Rural development administration, Korea) (2012) Quality control and utilization of livestock manure. National institute of agricultural sciences, Jeon Ju. (11-1390802-000592-01)

27. Sanchez-Monedero MA, Serramia N, Civantos CGO, Fernandez-Hernandez A, Roig A (2010) Greenhouse gas emissions during composting of twophase olive mill wastes with different agroindustrial by-products. Chemosphere 81:18-25

28. Zhang J, Lü F, Shao L, He P (2014) The use of biochar-amended composting to improve the humification and degradation of sewage sludge. Bioresour Technol 168(3):252-258

29. Chan M, Selvam A, Wong JWC (2016) Reducing nitrogen loss and salinity during 'struvite' food waste composting by zeolite amendment. Bioresour Technol 200:838-844

30. Chowdhury MA, Neergaard A, Jensen LS (2014) Potential of aeration flow rate and biochar addition to reduce greenhouse gas and ammonia emissions during manure composting. Chemosphere 97(1):16-25

31. Yang F, Li Y, Han YH, Qian W, Li G, Luo W (2019) Performance of mature compost to control gaseous emissions in kitchen waste composting. Sci Total Environ 657:262-269

32. Sommer SG (2001) Effect of composting on nutrient loss and nitrogen availability of cattle deep litter. Eur J Agron 14(2):123-133

33. El Kader NA, Robin P, Paillat JM, Leterme P (2007) Turning, compacting and the addition of water as factors affecting gaseous emissions in farm manure composting. Bioresour Technol 98:2619-2628

34. Ahn HK, Mulbry W, White JW, Kondrad SL (2011) Pile mixing increases greenhouse gas emissions during composting of dairy manure. Bioresour Technol 102:2904-2909

35. Wang S, Zheng Y (2017) Ammonia emission mitigation in food waste composting: a review. Bioresour Technol. https://doi.org/10.1016/j.biort ech.2017.07.050

36. Han X, Hu C, Xia X, Chen Y (2018) Soil carbon and nitrogen sequestration and crop growth as influenced by long-term application of effective microorganism compost. Chil J Agric Res 78(1):13-22

37. Gea T, Barrena R, Artola A, Sanchez A (2007) Optimal bulking agent particle size and usage for heat retention and disinfection in domestic wastewater sludge composting. Waste Manag 9:1108-1116

38. Zhang L, Sun X (2014) Changes in physical, chemical an microbiological properties during the two-stage co-composting of green waste with spent mushroom compost and biochar. Bioresour Technol 171:274-284

39. Huang J, Yu Z, Gao H, Yan X, Chang J, Wang C, Hu J, Zhang L (2017) Chemical structures and characteristics of animal manures and composts during composting and assessment of maturity indices. PLoS ONE 12:e0178110

40. Awasthi MK, Pandey AK, Bundela PS, Khan J (2015) Co-composting of organic fraction of municipal solid waste mixed with different bulking 
waste: characterization of physicochemical parameters and microbial enzymatic dynamic. Bioresour Technol 182:200-207

41. Chen H, Awasthi MK, Liu T, Zhao J, Xiuna R, Wang M, Duan Y, Awasthi SK, Zhang Z (2018) Influence of clay as additive on greenhouse gases emission and maturity evaluation during chicken manure composting. Bioresour Res 266:82-88

42. Wang X, Selvam A, Chan MT, Wong JWC (2013) Nitrogen conservation and acidity control during food wastes composting through struvite formation. Bioresour Technol 147:17-22

43. He Z, Lin H, Hao J, Kong X, Tian K, Bei Z, Tian X (2018) Impact of vermiculite on ammonia emissions and organic matter decomposition of food waste during composting. Bioresour Technol 263:548-554

44. Luo WH, Yuan J, Luo YM, Li GX, Nghiem LD, Price WE (2014) Effects of mixing and covering with mature compost on gaseous emissions during composting. Chemosphere 117:14-19
45. Jiang T, Schuchardt F, Li GX, Guo R, Luo YM (2013) Gaseous emission during the composting of pig feces from Chinese Ganqinfen system. Chemosphere 90:1545-1551

46. Tiquia SM, Tam NFY, Hodgkiss IJ (1996) Effects of composting on phytotoxicity of spent pig-manure sawdust litter. Environ Pollut 93(3):249-256

\section{Publisher's Note}

Springer Nature remains neutral with regard to jurisdictional claims in published maps and institutional affiliations.

\section{Submit your manuscript to a SpringerOpen ${ }^{\circ}$ journal and benefit from:}

- Convenient online submission

- Rigorous peer review

- Open access: articles freely available online

- High visibility within the field

- Retaining the copyright to your article

Submit your next manuscript at $\boldsymbol{\nabla}$ springeropen.com 